\title{
Factors Affecting Waste Generation: Household Study in Palangka Raya City, Central Kalimantan
}

\author{
$H$ Herianto $^{1, *}$, Maryono $^{2}$, and Mochamad Arief Budihardjo $^{3}$ \\ ${ }^{1}$ Master Program in Environmental Science, School of Postgraduate Studies, Diponegoro University, Semarang - Indonesia \\ ${ }^{2}$ Department of Urban Regional Planning, Faculty of Engineering, Diponegoro University, Semarang - Indonesia \\ ${ }^{3}$ Department of Environmental Engineering, Faculty of Engineering, Diponegoro University, Semarang - Indonesia
}

\begin{abstract}
Domestic waste from households is the biggest contributor to municipal waste management. Palangka Raya City is one of the cities that faces waste problems due to lack of awareness of the citizens. The culture of dumping garbage into river bodies is common for residents who live along the river banks. This study aims to determine waste generation and the factors affecting waste generation of household in the Palangka Raya City. The measurement of waste generation was carried out in accordance with the guidelines of SNI 19-3964-1994, while the variables that are suspected to influence the waste generation were collected by the questionnaire. To find out the factors affecting waste generation, data were analyzed by multiple linear regression. Based on the results of research conducted on 48 respondents obtained household waste generation in Palangka Raya City is $0.33 \mathrm{~kg} / \mathrm{person} /$ day, while significant factors affecting waste generation are concern for the environment and income levels at a $95 \%$ confidence level and the number of family members at the $99 \%$ confidence level. While the recycling knowledge, education level, house size and installed electrical power did not significantly affect waste generation. With this information, it can be calculated the needs of TPS, the needs of the transport fleet, the needs of cleaning staff and plans for controlling household waste generation in the Palangka Raya City.
\end{abstract}

Keywords: Waste generation; domestic waste; waste management.

\section{Introduction}

Garbage is a problem of cities, both large cities and small cities. City waste management is the sixth target in the eleventh goal of Sustainable Development Programs (SDGs) namely "making cities and inclusive, safe, resilient and sustainable settlements" proclaimed by the United Nations Agency (UN) to be achieved in 2030 $[1,2]$.

One of the cities that faces garbage problems is the City of Palangka Raya. Palangka Raya is the Capital of Central Kalimantan Province with a population in 2017 of 267,757 people. This figure increased from 2016 with a population growth rate of 2.95 percent [3]. Data from waste management agencies in the Palangka Raya city, that the level of waste services in 2018 is $47.72 \%$. More than half the volume of waste produced is disposed of in a way that is not supposed to and has the potential to reduce the quality of the surrounding environment and endanger the health of the environment. In addition, with the discourse of moving the Capital City of the Republic of Indonesia to Palangka Raya and promoting urban growth, optimal waste services are needed. With this in mind, basic solid waste data is needed so that it is expected to support the preparation of a waste management plan. With good planning documents, it is expected to improve waste services in Palangka Raya City.

Research in waste management that has been conducted in Palangka Raya City includes research on optimizing the performance of waste management. The results of the study revealed that problems in waste management in Palangka Raya City were still limited human resources, limited funding, transportation systems that were still not optimal and low public awareness in supporting waste management carried out by local governments [4]. However, the research did not measure waste generation from sources and analysis of the factors that influence waste generation from households was not carried out.

Research on factors that affect the rate of waste generation has been carried out by several researchers, the results of the study show that household waste generation is significantly influenced by household size, income, environmental concern, and willingness to separate waste [5]. This information can be used by the local government to improve waste management, improve waste management performance, and can be used to reduce environmental degradation from household waste. The same thing was also found by other researchers who found that income levels could be used to predict waste generation. The higher income will increase waste production [6].

\footnotetext{
${ }^{*}$ Corresponding author: heridkl@gmail.com
} 
This study aims to study the rate of waste generation and the factors that influence the rate of waste generation from households in the City of Palangka Raya. Information on waste generation and the factors that influence the rate of waste generation are very important in preparing waste management plans to improve solid waste services in the City of Palangka Raya.

\section{Material and Method}

\subsection{Study area}

This research took place in the City of Palangka Raya, the Capital City of Central Kalimantan Province. Palangka Raya city is administratively composed of 5 sub-districts and 30 villages. But in this study only limited to 7 urban villages in the city because it was considered important for research. The selection of the study area was based on the consideration that more than $80 \%$ of the population of the Palangka Raya City lived in these 7 urban villages. The urban villages that became the research area were Pahandut, Pahandut Seberang, Panarung, Langkai, Palangka, Menteng and Bukit Tunggal. For details, the location of the study can be seen in Figure 1.

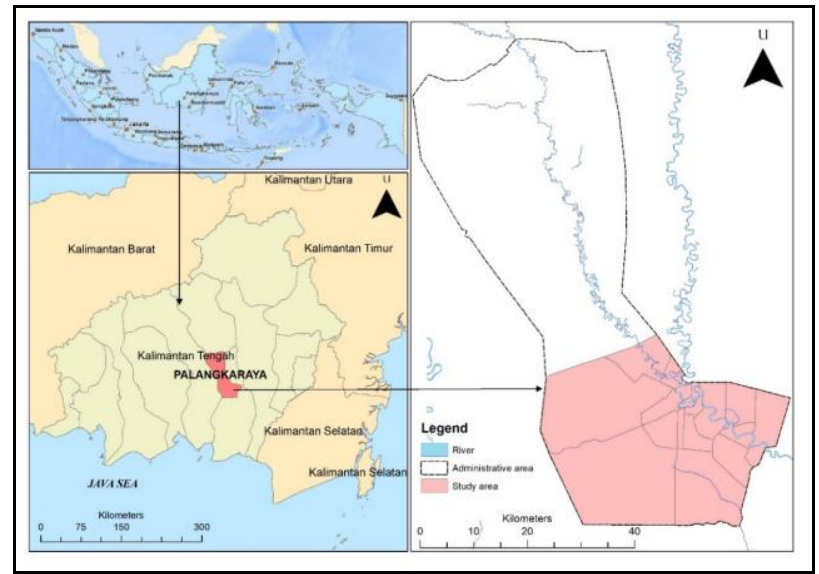

Fig. 1. Study area

\subsection{Population and sample}

The population of this study is all households from the study area. Based on BPS data that in 2017 the population in the study area was 233,605 [7]. The number of samples used in this study follows the guidelines in SNI 19-3964-1994, based on the calculation results, the number of research samples is 48 households. Then in the sample selection of households selected by stratified random sampling from the group of permanent houses / high income as many as $12(25 \%)$, semi-permanent houses / middle income as many as 14 $(30 \%)$ and non-permanent / low income houses as much as $22(45 \%)$. The total sample of 48 has met the sample size of the regression test, which is between 30-500 samples [8].

\subsection{Research instrument}

To obtain the waste generation data, measurements were carried out following the standards of SNI 19-39641994, namely by measuring the weight of household/domestic waste every day for 8 consecutive days from a selected household sample. The research equipment used to measure waste generation was a $10 \mathrm{~kg}$ capacity scale, as well as supporting equipment including plastic bags, gloves, masks, and writing equipment. The results of the measurement of waste weight were expressed as the dependent variable (y).

Meanwhile, to collect data on the independent variable (x) which was considered to affect the waste generation, data was collected by the questionnaire. The respondent in the questionnaire is the head of the household chosen in the measurement of waste generation, so the number of questionnaires in this study was 48 . The questionnaire in this study was divided into three sessions, namely A, B and C. Session A was used to identify respondents' knowledge and concerns about the environment. Session B was used to identify knowledge of respondents regarding recycling of trash and session $\mathrm{C}$ was used to determine the socio-economic information of respondents.

To determine the level of knowledge and concern of respondents to the environment in session A questions are calculated by scoring. To get a range of scores by adding up the smallest accumulated value with the largest value divided by the interval you want to use. In study it was divided into two intervals, namely caring for the environment and not caring about the environment. If the number of scores produced is in the first interval range, which is not concerned with the eating environment, the final score is " 0 " and if the score produced is in the second interval range, which is concerned with the environment, the final score is " 1 ".

Likewise for session B questions, the total score was divided into two interval ranges, namely respondents had knowledge about good recycling of garbage and knowledge about recycling of garbage is not good. If the score produced is in the first interval range, namely the knowledge of recycling rubbish garbage is not good given the final value of " 0 " and if the score produced is in the second interval range that is knowledge about recycling good rubbish garbage is given the final value "1". While for session C questions, the questionnaire data was directly entered according to the respondents' answers.

\subsection{Data analysis}

\subsubsection{Waste generation in the household}

The method of calculating the rate of waste generation according to SNI 19-3964-1994, with the following formula :

$W G=T s=V s \times u^{-1} \times t^{-1}$ 
where:

Ts waste generation of each study sample $(\mathrm{kg} / \mathrm{person} /$ day $)$

Vs the volume of waste measured (kilogram)

$\mathrm{u}$ number of waste generating units (person)

$\mathrm{t}$ number of sampling days ( 8 days)

\subsubsection{Factors afecting waste generation}

To model the relationship between one dependent variable (y) with more than one independent variable (x), the analysis used was multiple linear regression analysis. The dependent variable in this study was waste generation, while the independent variables were behavioral and attitudinal factors towards the environment and socio-economic factors. In general the relationship model can be stated as follows :

$$
W G=Y=\beta_{0}+\beta_{1} X_{1}+\beta_{2} X_{2}+\cdots+\beta_{n} X_{n}
$$

where:

$W G$ waste generation

$X_{n}$ independent variable

$\beta_{0} \quad$ constants or intercept

$\beta_{n} \quad$ independent variable coefficients

$n$ number of variables

To determine the relationship of independent variable (x) that affects the rate of waste generation (y) a t test was carried out, while to find out the model of the relationship between the dependent variable (y) and the independent variable ( $\mathrm{x}$ ), an $\mathrm{F}$ test was performed determination $\left(\mathrm{R}^{2}\right)$ which is an indicator of the closeness of the interplay between the independent variable $(\mathrm{x})$ on the dependent variable (y) as the target or targets search final results of the study. Table 1 below was the independent variable used in this study.

Table 1. Variables in the regression model

\begin{tabular}{|c|c|}
\hline Variabel & Definition \\
\hline Waste generation $(\mathrm{y})$ & $\begin{array}{c}\text { Average household waste weight for } \\
8 \text { consecutive days }\end{array}$ \\
\hline $\begin{array}{c}\text { Concern for the } \\
\text { environment }\left(\mathrm{x}_{1}\right)\end{array}$ & $\begin{array}{c}\text { Dummy to represent caring for the } \\
\text { environment "1" and no matter "0" }\end{array}$ \\
\hline $\begin{array}{c}\text { Knowledge about } \\
\text { recycling }\left(\mathrm{x}_{2}\right)\end{array}$ & $\begin{array}{c}\text { Dummy to represent knowing the } \\
\text { concept of recycling "1" and not } \\
\text { knowing "0" }\end{array}$ \\
\hline Family number $\left(\mathrm{x}_{3}\right)$ & $\begin{array}{c}\text { Number } \\
\text { Education }\left(\mathrm{x}_{4}\right)\end{array}$ \\
\hline Income $\left(\mathrm{x}_{5}\right)$ & $\begin{array}{c}\text { Dummy to represent undergraduate } \\
\text { education "1" and not undergraduate } \\
\text { "0" }\end{array}$ \\
\hline House area $\left(\mathrm{x}_{6}\right)$ & $\begin{array}{c}\text { Number for household income per } \\
\text { month }\end{array}$ \\
\hline $\begin{array}{c}\text { Electric power is } \\
\text { installed }\left(\mathrm{x}_{7}\right)\end{array}$ & $\begin{array}{c}\text { Dummy to represent 1,300 VA or } \\
\text { more "1" electric power and below } \\
1,300 \text { VA "0" }\end{array}$ \\
\hline
\end{tabular}


facilities such as densely populated residential areas on the Kahayan River. Based on the results of additional information in the questionnaire, respondents from the area admitted that it is difficult to access waste facilities. Although there is less waste generation from low-income households, because they live in areas that are difficult to access solid waste facilities, this provides an opportunity for them to dispose of garbage irresponsibly to river bodies such as culture and customs so far.

\subsection{Estimation results of waste generation and social-economic model}

Based on the results of multiple linear regression analysis of the variables tested, the factors that influence waste generation are shown as shown in Table 3 .

Table 3. Factors affecting waste generation

\begin{tabular}{|c|c|c|}
\hline Variabel & t statistik & Sig. \\
\hline Concern for the environment & -2.541 & 0.015 \\
\hline Knowledge about recycling & 0.362 & 0.720 \\
\hline Family number & 3.207 & 0.003 \\
\hline Education & -1.501 & 0.141 \\
\hline Income & 2.673 & 0.011 \\
\hline House area & 0.430 & 0.669 \\
\hline Electric power is installed & 0.609 & 0.546 \\
\hline
\end{tabular}

Based on Table 3, it is known that the factors that influence household waste generation in Palangka Raya City concern for the environment variables and income level at a 95\% confidence level. While the variable number of family members at $99 \%$ confidence level. The $t$ value of concern for the environment variable has a negative correlation, meaning that the lower the level of concern will increase the waste generation. This finding is in line with the results of previous studies [5]. While the value of $t$ count the number of family members and income level has a positive correlation, meaning that more number of family members and higher the income of a household, more increase waste production. Information on the significance of this influence can be used by local governments in predicting the generation of residential solid waste, this is also in accordance with the results of previous studies which state that the level of income can be used to predict solid waste generation [6]. While the variable knowledge of recycling, level of education, size of the house and installed electric power do not significantly affect the generation of waste. What is interesting from the results of this study is that the level of education also has a negative correlation to the generation of waste, although it does not significantly affect the generation of waste, it can be interpreted that the higher level of education the head of the household will relatively produce less waste. This is presumably because, with a higher level of education, they have good understanding and awareness of the environment so that it will reduce the production of household waste.

With this information can be used by local governments in an effort to control the waste generation from its source. One effort that can be done by local governments is by promoting socialization to the community so that public awareness of the environment increases. Based on the data, socialization activities are prioritized for community groups with lower levels of education and densely populated settlements such as the Kahayan Riverbank area in the hope of increasing citizens' awareness of the environment.

While based on the F test a value of 4.873 is obtained with a significant level of sig. $0.00<\alpha=0.05$ means that the regression model can be used to predict waste generation. The garbage generation prediction model in Palangka Raya City is as follows:

$$
\begin{aligned}
\mathrm{Ts}= & -0,088-0,565 \mathrm{X}_{1}+0,069 \mathrm{X}_{2}+0,176 \mathrm{X}_{3}-0,343 \mathrm{X}_{4}+ \\
& 0,153 \mathrm{X}_{5}+0,080 \mathrm{X}_{6}+0,001 \mathrm{X}_{7}
\end{aligned}
$$

While based on the value of the determination index $\left(\mathrm{R}^{2}\right)$ the value obtained is 0.460 , it means that the independent variable tested influences waste generation by $46 \%$ and the remaining $54 \%$ is influenced by other factors outside the variables tested in this study.

\section{Conclusion}

Waste generation originating from households in Palangka Raya City is estimated at $0.33 \mathrm{~kg} /$ person / day with a significant factor affecting waste generation from households is concern for the environment and income level at a $95 \%$ confidence level. While the number of family members affects waste generation at a $99 \%$ confidence level. This variable which has a significant level can be used to predict the generation of residential waste. With this waste generation information can be calculated the need for waste facilities such as the number of polling stations, transport fleets, janitors and financing needs. While based on the data of factors that influence the waste generation, it can be arranged a plan to control waste generation from settlements such as increasing socialization activities through appropriate information media or by optimizing the organization of garbage banks that have been formed by Palangka Raya City Environment Agency.

\section{References}

1. UN, The Sustainable Development Agenda, 2016. [Daring]. Tersedia pada: https://www.un.org/sustainabledevelopment/develop ment-agenda/. [Diakses: 11-Des-2018].

2. W. Sarosa, M. D. Isnutomo, G. E. Virant, D. Sarahidha, \& N. A. Susetyo, Panduan Praktis Implementasi Agenda Baru Perkotaan Untuk Kota Berkelanjutan di Indonesia. Jakarta: Kementerian Pekerjaan Umum dan Perumahan Rakyat Republik Indonesia (2017)

3. BPS, Statistik Daerah Kota Palangka Raya 2018. Palangka Raya: Badan Pusat Statistik Kota Palangka Raya (2018)

4. E. Triani, Optimalisasi Kinerja Pengelolaan 
Sampah di Kota Palangka Raya, Institut Teknologi Sepuluh Nopember (2017)

5. R. Afroz, K. Hanaki, dan R. Tudin, Factors affecting waste generation: A study in a waste management program in Dhaka City, Bangladesh, Environ. Monit. Assess., 179, 1-4: 509-519 (2011)

6. N. J. G. J. Bandara, J. P. A. Hettiaratchi, S. C. Wirasinghe, dan S. Pilapiiya, "Relation of waste generation and composition to socio-economic factors: A case study," Environ. Monit. Assess., 135, 1-3: 31-39 (2007)

7. BPS, Kota Palangka Raya dalam Angka 2018.
Palangka Raya: Badan Pusat Statistik Kota Palangka Raya (2018)

8. Sugiyono, Metode Penelitian Kuantitatif Kualitatif dan R\&D. Bandung: Alfabeta (2012)

9. S. Widodo dan N. A. Firdaus, Studi Timbulan Dan Komposisi Sampah Rumah Tangga Kota Magelang, J. Georafflesia, 3, 2: 74-80 (2018)

10. Y. Dewilda, Y. Darnas, dan I. Zulfa, Satuan Timbulan dan Komposisi Sampah Domestik Kabupaten Tanah Datar, J. Dampak, 11, 1: 28-33 (2014) 